\title{
Lysosomal enzyme cytochemistry of blood neutrophils
}

\author{
J. T. WOZNIAK, T. L. ORCHARD, P. H. MACKIE, D. K. MISTRY, AND \\ J. STUART
}

From the Department of Haematology, Queen Elizabeth Hospital, Birmingham B15 2TH, UK

SUMMARY Patients with bacterial infection may show altered membrane permeability of the primary azurophilic lysosomes of blood neutrophils. A new enzyme cytochemical technique, sensitive to increased membrane permeability caused by contact of neutrophils with acetone saponin, low pH, Streptolysin O, bacteria, and nylon wool, has been developed. The method is of potential value as a screening test for bacterial infection and for detecting neutrophil damage during filtration leucopheresis.

The cytoplasm of the human blood neutrophil is characterised by primary azurophilic lysosomal granules, formed at the promyelocytic stage of differentiation, and secondary specific granules formed at the later, myelocyte stage (Bainton and Farquhar, 1966; Bainton et al., 1971; Bainton, 1975).

The membranes of these lysosomes normally remain impermeable (De Duve, 1969) until the neutrophil exerts its bactericidal role, when lysosomal enzymes are released (Cohn and Hirsch, 1960). Minor damage to lysosomes can, however, cause increased membrane permeability to substances such as enzyme substrate without causing enzyme release (Allison and Mallucci, 1965). The toxic granulation of blood neutrophils in severe bacterial infection probably represents increased permeability of primary lysosomal membranes to Romanowsky stains (McCall et al., 1969) and may either be acquired by the mature neutrophil in the blood (Gordin, 1952; McCall et al., 1973; Wintrobe, 1974) or result from abnormal marrow development or early release (Cline, 1975).

The use of cytochemical methods that are sensitive to altered permeability of primary lysosomal membranes may therefore provide a more sensitive and specific test for bacterial infection than either toxic granulation, the nitroblue tetrazolium (NBT) test, or the neutrophil alkaline phosphatase (NAP) score, which give false positive and negative results (Hayhoe and Quaglino, 1958; Segal, 1974; Steigbigel et al., 1974).

Received for publication 8 December 1977
The histochemical technique for acid phosphatase is ideal for testing lysosomal membrane permeability since the $\beta$-glycerophosphate substrate does noto penetrate the intact membrane of normal cells (Des Duve, 1959). Existing cytochemical methods use fixed blood films, however, and fixation itselfô renders these membranes fully permeable (Allison $\mathbb{D}$ and Mallucci, 1965). An alternative approach was, $\overrightarrow{\vec{B}}$ therefore, developed, using an unfixed leucocyte 3 concentrate suspended in an incubation solution of? physiological osmolality, for both acid phosphatase and a second primary lysosomal enzyme, chloroacetate esterase.

\section{Cytochemical methods}

LEUCOCYTE-RICH PLASMA

Cytochemical studies were performed on leucocyte- $>$ rich plasma (LRP) prepared by sedimenting erythro- $\frac{7}{0}$ cytes from $5 \mathrm{ml}$ heparinised blood samples layered on to dextran-Triosil for 30 minutes at room $\tilde{\sigma}^{N}$ temperature. The dextran-Triosil layer was prepared by mixing $5 \mathrm{ml} \mathrm{3.6 \%} \mathrm{w/v} \mathrm{Dextran} \mathrm{T500} \mathrm{(Pharmacia)}$ in distilled water with $1 \mathrm{ml}$ Triosil 440 (Nyegaard) in a siliconised glass McCartney bottle and was then sterilised by autoclaving. The LRP layers were aspirated using a plastic pipette and pooled, and $0.5-1 \mathrm{ml}$ aliquots were used for each cytochemical reaction. When five replicate experiments were per- $\frac{T}{T}$ formed the aliquots were taken from a pool of LRP derived from one individual.

CHLOROACETATE ESTERASE

The LRP was pipetted into a $5-\mathrm{ml}$ graduated plastic 8 648 
tube and phosphate buffered saline (PBS) at $\mathrm{pH} 7 \cdot 3$ was added to $5 \mathrm{ml}$ before centrifugation at $500 \mathrm{~g}$ for one minute. The supernatant was discarded and the cell pellet resuspended by agitation on a vortex mixer for 5 seconds. Freshly made incubation medium $(5 \mathrm{ml})$ at $37^{\circ} \mathrm{C}$ was added before incubation in a water bath at $37^{\circ} \mathrm{C}$ for 10 minutes.

\section{Incubation medium}

$a$ Tris-acetate buffer $0.1 \mathrm{M}, \mathrm{pH} 7 \cdot 4$, containing $1 \% \mathrm{w} / \mathrm{v}$ polyvinylpyrrolidone (PVP), MW 40000 (Sigma)-25 ml

$b$ Sodium nitrite solution $4 \% \mathrm{w} / \mathrm{v}$

$c$ New fuchsin (Gurr) solution $-4 \% \mathrm{w} / \mathrm{v}$ in $\mathrm{N} \mathrm{HCl}$

$d$ Naphthol AS-D chloroacetate (Sigma)-3.0 mg

$e$ N,N-dimethylformamide (British Drug Houses) $100 \mu 1$

The new fuchsin solution was hexazotised by mixing with an equal volume of sodium nitrite and the mixture was allowed to stand at room temperature for one minute. The buffer was pre-warmed to $37^{\circ} \mathrm{C}$ and $250 \mu \mathrm{l}$ of hexazotised new fuchsin solution was added. The substrate was dissolved in the dimethylformamide, added to the buffered fuchsin, mixed, and used immediately. The PVP was added to prevent precipitation of substrate during the reaction. All incubation media used in this study were adjusted to a final osmolality within the physiological range (275-300 mosmol $/ \mathrm{kg})$.

After incubation the tube was centrifuged at $500 \mathrm{~g}$ for one minute, the supernatant was discarded, any residuum being drained on to absorbent paper, and the cells were resuspended by vortex mixing in one drop (approximately $20 \mu \mathrm{l}$ ) of 5\% Dextran T500 in PBS. One drop of the cell suspension was then smeared on to a glass slide, rapidly dried in warm air, and fixed in formol-acetone $(3 \mathrm{ml}$ formalin, $5 \mathrm{ml}$ acetone, and $2 \mathrm{ml}$ water) for 30 seconds at $4^{\circ} \mathrm{C}$. The film was counterstained for 60 seconds using Mayer's haematoxylin.

A semiquantitative cytochemical score of the red cytoplasmic reaction product in 100 discrete polymorphs was made as follows:

Grade 0 no colour

1 a few cytoplasmic granules only

2 many granules with, occasionally, a pale diffuse colour

3 deep diffuse colour

The number of cells in each grade was multiplied by the grade number and summed to give a weighted score with a maximum of 300 .

\section{ACID PHOSPHATASE}

This azo dye method was similar to that for chloroacetate esterase except that the incubation period was 60 minutes. The score was expressed as the per- centage of 100 discrete neutrophils containing a diffuse deep pink reaction product.

\section{Incubation medium}

a Acetate buffer $0 \cdot 1 \mathrm{M}, \mathrm{pH} 5 \cdot 6$, containing $1 \% \mathrm{w} / \mathrm{v}$ PVP-25 ml

$b$ Sodium nitrite solution $4 \% \mathrm{w} / \mathrm{v}$

$c$ New fuchsin (Gurr) solution $-4 \% \mathrm{w} / \mathrm{v}$ in $\mathrm{N} \mathrm{HCl}$

$d$ Naphthol AS-BI phosphoric acid (prepared according to Burstone, 1962)-25 mg

$e \mathrm{~N}, \mathrm{~N}$-dimethylformamide (BDH) $-100 \mu \mathrm{l}$

NITROBLUE TETRAZOLIUM (NBT) TEST

A modification of the method of Gordon et al. (1975) was used. Equal volumes $(250 \mu \mathrm{l})$ of LRP and NBT (British Drug Houses) solution (1 $\mathrm{mg} / \mathrm{ml}$ in PBS) were incubated at $37^{\circ} \mathrm{C}$ for 10 minutes, and $100 \mu l$ $15 \% \mathrm{w} / \mathrm{v}$ Dextran T500 (Pharmacia) was added before mixing on a vortex mixer. One drop of the resulting cell suspension was smeared on a glass slide, fixed, and counterstained as in the esterase technique. The percentage of neutrophils containing a clearly visible black formazan deposit was determined by counting 100 discrete cells.

NEUTROPHIL ALKALINE PHOSPHATASE (NAP)

The kit method, based on Ackerman (1962), of the Sigma Chemical Company was used to determine the NAP score in 100 neutrophils on a blood film which had been fixed in $10 \% \mathrm{v} / \mathrm{v}$ formol-methanol at $4^{\circ} \mathrm{C}$ for 30 seconds. The films were then counterstained for 3 minutes with $0 \cdot 1 \%$ aqueous neutral red.

This procedure differed from the primary lysosomal enzyme and NBT methods in that the cells were air-dried and fixed before the cytochemical reaction.

\section{Statistical methods}

Statistical significance was determined by Student's $t$ test.

\section{Results}

\section{CHOICE OF ANTICOAGULANT}

There was no apparent difference in reaction product for the primary lysosomal enzymes using either heparin (Weddel Pharmaceuticals) at a final concentration of $20 \mathrm{iu} / \mathrm{ml}$, dipotassium EDTA $1 \cdot 5 \mathrm{mg} / \mathrm{ml}$, or citrate $0.38 \% \mathrm{v} / \mathrm{v}$. Mucous heparin was therefore used for all lysosomal studies.

EFFECT OF CELL DRYING

When aliquots of LRP were added to the incubation media there was little or no visible reaction endpro duct, but if the LRP was first smeared on to a 
glass slide and air-dried at room temperature for five minutes then a strong reaction product was obtained (Table 1). Smeared, dried cells also allowed penetration of trypan blue. The effect of drying, rather than the method of transfer to the slide or the effect of glass contact, appeared to render permeable the cytoplasmic and lysosomal membranes of the cells. Fixation of these air-dried cells in acetone, formolacetone, or formalin did not result in any further increase in reaction product.

Table 1 Effect on enzyme scores of cell drying compared with cells maintained in suspension

\begin{tabular}{llll}
\hline & \multicolumn{3}{l}{ Cytochemical reaction score } \\
\cline { 2 - 4 } & $\begin{array}{l}\text { Chloroacetate } \\
\text { esterase }\end{array}$ & $\begin{array}{l}\text { Acid } \\
\text { phosphatase }\end{array}$ & $\begin{array}{l}\text { Trypan blue } \\
\text { exclusion (\%) }\end{array}$ \\
\hline $\begin{array}{l}\text { Cell suspension } \\
\begin{array}{l}\text { Dried smear on glass } \\
\text { Dried smear on Perspex } \\
\text { Dried cytocentrifuge } \\
\text { preparation on glass }\end{array}\end{array}$ & 300 & 0 & 100 \\
\hline
\end{tabular}

The cell suspension technique was therefore adopted for all subsequent studies of primary lysosomal membrane permeability. By comparison, the alkaline phosphatase reaction was performed on air-dried fixed cells with fully permeable membranes.

\section{EFFECTS OF PHYSICAL AGENTS}

\section{Acetone preincubation}

Aliquots of $0.5-1.0 \mathrm{ml}$ LRP were resuspended in $5.0 \mathrm{ml}$ PBS and acetone was added to give final concentrations of $0 \%, 1 \%, 4 \%$, and $8 \% \mathrm{v} / \mathrm{v}$. After five minutes' exposure to acetone at $37^{\circ} \mathrm{C}$ the cell suspension was centrifuged at $500 \mathrm{~g}$ for one minute and the cell pellet was washed once in PBS before each cytochemical reaction.

The results are shown in Table 2. A $4 \%$ final concentration of acetone resulted in a significant increase in activity of acid phosphatase, while both primary lysosomal enzymes showed a significant increase after preincubation in $8 \%$ acetone. There was no significant increase in the alkaline phosphatase score of neutrophils with membranes which had previously been rendered fully permeable. Acetone did not increase penetration and reduction of NBT; the NBT score, in fact, decreased slightly.

\section{Saponin preincubation}

A similar experiment was performed using five minutes' preincubation in saponin at concentrations of $0 \%, 0.001 \%$, and $0.005 \% \mathrm{w} / \mathrm{v}$.

The results (Table 3 ) show a significant increase in
Table 2 Effect of acetone preincubation on enzyme scores (mean $\pm S E M$ for five experiments)

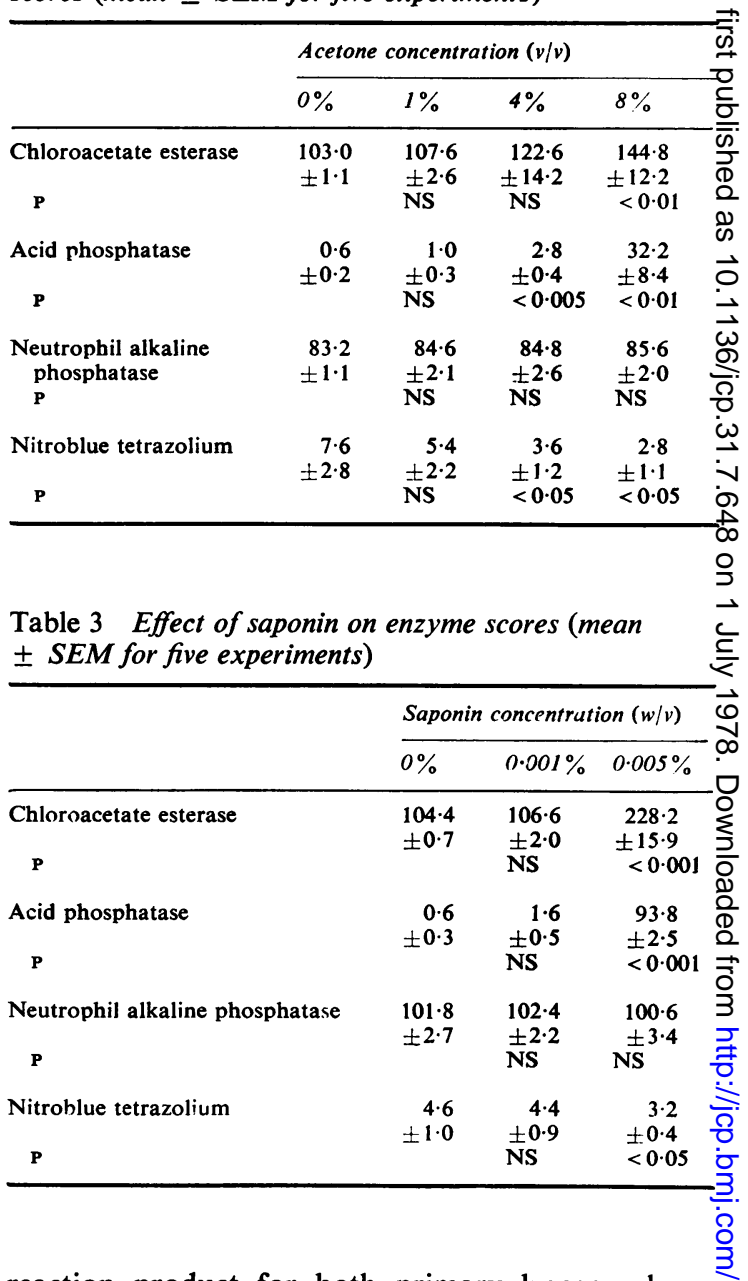

reaction product for both primary lysosomal en- $\circ$ zymes at a saponin concentration of $0.005 \%$, but again there was no increase in alkaline phosphatase activity in air-dried neutrophils or in the NBT score.

\section{pH change}

Tris maleate buffer $(0 \cdot 15 \mathrm{M})$ at $\mathrm{pH} 4 \cdot 0,5 \cdot 0,6 \cdot 0$, and $7 \cdot 0$ was adjusted to physiological osmolality with ${ }_{0}^{\omega}$ distilled water and warmed to $37^{\circ} \mathrm{C}$. The leucocytes from approximately $3 \mathrm{ml}$ LRP were preincubated in? the buffer for five minutes at $37^{\circ} \mathrm{C}$ and then washed, as before, prior to the chloroacetate esterase cytochemical reaction, performed at a $\mathrm{pH}$ of $7 \cdot 4$. The results are shown in Table 4. Preincubation at $\mathrm{pH} 7 \cdot 0 \stackrel{\mathrm{D}}{\mathrm{D}}$ was taken as the control value, and statistical sig- $\frac{?}{\mathrm{D}}$ nificance for the other $\mathrm{pH}$ values was calculated by 0 comparison. Lowering the $\mathrm{pH}$ below 5.0 resulted in a significant increase in cytochemical reaction product. 8 
Table 4 Effect of preincubation at low pH, compared with a control at $\mathrm{pH} 7 \cdot 0$, on chloroacetate esterase (mean $\pm S E M$ for five experiments)

\begin{tabular}{lllll}
\hline \multicolumn{5}{c}{ Preincubation $p H$} \\
\cline { 2 - 5 } & 7.0 & 6.0 & 5.0 & 4.0 \\
\hline Chloroacetate esterase & 106.6 & 105.0 & 109.4 & 143.2 \\
& \pm 1.9 & \pm 1.5 & \pm 3.7 & \pm 8.6 \\
$\mathrm{P}$ & & $\mathrm{NS}$ & $\mathrm{NS}$ & $<0.005$ \\
\hline
\end{tabular}

\section{EFFECTS OF BACTERIA AND BACTERIAL} PRODUCTS

\section{Endotoxin}

To $1 \mathrm{ml} \mathrm{LRP} \mathrm{was} \mathrm{added} \mathrm{either} 1 \mathrm{ml} \mathrm{N}$ saline or $1 \mathrm{ml} \mathrm{N}$ saline containing $2 \mathrm{mg}$ Escherichia coli endotoxin (Difco). Preincubation was carried out for 60 minutes at $37^{\circ} \mathrm{C}$. The centrifuged cell pellets were then washed and tested cytochemically as before. For the nitroblue tetrazolium test the cell pellet was instead resuspended in $250 \mu \mathrm{l}$ prewarmed autologous plasma, and an equal volume of prewarmed NBT solution (Gordon et al., 1975) was added before incubation at $37^{\circ} \mathrm{C}$ for 10 minutes. The suspension was then made up to $5 \mathrm{ml}$ using PBS, centrifuged at $500 \mathrm{~g}$ for one minute, and drained. The cell deposit was resuspended in one drop of PBS containing $5 \%$ dextran and smears were air-dried on to glass slides. These were fixed in formol-acetone at $4^{\circ} \mathrm{C}$ for 30 seconds and counterstained with neutral red for three minutes. The percentage of neutrophils containing a definite formazan deposit was counted.

Endotoxin increased the NBT score but had no other significant effect (Table 5).

Table 5 Effect on enzyme scores of preincubation with endotoxin for 60 minutes (mean $\pm S E M$ for five experiments)

\begin{tabular}{lcc}
\hline & Control & Endotoxin \\
\hline Chloroacetate esterase & 103.0 & $99 \cdot 2$ \\
& $\pm 1 \cdot 1$ & \pm 2.2 \\
P & & NS \\
Acid phosphatase & 2.4 & 2.6 \\
P & \pm 0.5 & \pm 0.8 \\
Neutrophil alkaline phosphatase & 62.0 & NS \\
P & \pm 3.6 & 59.4 \\
Nitroblue tetrazolium & & \pm 2.0 \\
P & 18.0 & NS \\
& \pm 2.5 & 38.8 \\
& & \pm 5.4 \\
\hline
\end{tabular}

Streptolysin $O$

A 1 in 100 dilution of Streptolysin O reagent (Difco) in PBS was made up immediately before use, and $2 \mathrm{ml}$ was preincubated for three minutes at $37^{\circ} \mathrm{C}$ with 1-ml aliquots of LRP. As previously, the cells were washed before cytochemical testing.

The results (Table 6) show a significant increase in activity of the primary lysosomal enzymes but no significant increase in NAP or NBT.

Table 6 Effect of Streptolysin $O$ on enzyme scores (mean $\pm S E M$ for five experiments)

\begin{tabular}{lcc}
\hline & Control & Streptolysin $O$ \\
\hline Chloroacetate esterase & 105.2 & 220.8 \\
& \pm 1.5 & \pm 7.0 \\
P & & $<0.001$ \\
Acid phosphatase & 1.0 & 89.0 \\
P & \pm 0.6 & \pm 2.9 \\
Neutrophil alkaline phosphatase & 79.4 & $<0.001$ \\
P & \pm 3.5 & 76.2 \\
Nitroblue tetrazolium & & \pm 4.0 \\
P & 6.4 & NS \\
\hline
\end{tabular}

\section{Phagocytosis of bacteria}

Heparinised venous blood $(4.5 \mathrm{ml})$ was incubated for 30 minutes at $37^{\circ} \mathrm{C}$ with $250 \mu \mathrm{l}$ of a bacterial suspension (final concentration of $10^{8}$ organisms $/ \mathrm{ml}$ ) or latex particles (final concentration of $10^{\circ}$ particles $/ \mathrm{ml}$ ). A blood film was then made for the NAP reaction, $250 \mu \mathrm{l}$ of blood was taken for the NBT test, and the remaining blood was separated on a dextran-Triosil layer for lysosomal enzyme cytochemistry.

The results (Table 7) show a significant increase in chloroacetate esterase activity after phagocytosis of all three organisms, and in acid phosphatase activity after phagocytosis of two of them. In con-

Table 7 Effect of phagocytosis on enzyme scores (mean $\pm S E M$ for five experiments)

\begin{tabular}{|c|c|c|c|c|c|}
\hline & Control & $\begin{array}{l}\text { Pseudo- } \\
\text { monas } \\
\text { aeru- } \\
\text { ginosa }\end{array}$ & $\begin{array}{l}\text { Staphylo- } \\
\text { coccus } \\
\text { albus }\end{array}$ & $\begin{array}{l}\text { Candida } \\
\text { albicans }\end{array}$ & $\begin{array}{l}\text { Latex } \\
\text { particles }\end{array}$ \\
\hline $\begin{array}{l}\text { Chloroacetate } \\
\text { esterase } \\
\quad \mathbf{P}\end{array}$ & $\begin{array}{r}101 \cdot 0 \\
\pm 0.5\end{array}$ & $\begin{array}{l}117.8 \\
\pm 4.6 \\
<0.01\end{array}$ & $\begin{array}{l}103.6 \\
\pm 0.8 \\
<0.05\end{array}$ & $\begin{array}{l}104.2 \\
\pm 0.9 \\
<0.05\end{array}$ & $\begin{array}{l}100 \cdot 6 \\
\pm 0 \cdot 5 \\
\text { NS }\end{array}$ \\
\hline $\begin{array}{l}\text { Acid } \\
\text { phosphatase } \\
\quad \text { P }\end{array}$ & $\begin{array}{r}0.2 \\
\pm 0.2\end{array}$ & $\begin{array}{l}16.0 \\
\pm 2.5 \\
<0.001\end{array}$ & $\begin{array}{l}2.8 \\
\pm 0.6 \\
<0.005\end{array}$ & $\begin{array}{l}1.4 \\
\pm 0.7 \\
\text { NS }\end{array}$ & $\begin{array}{l}1 \cdot 2 \\
\pm 0 \cdot 6 \\
\text { NS }\end{array}$ \\
\hline $\begin{array}{l}\text { Neutrophil alka- } \\
\text { line phosphatase } \\
\quad \text { P }\end{array}$ & $\begin{array}{r}76.4 \\
\pm 3 \cdot 2\end{array}$ & $\begin{array}{l}55.2 \\
\pm 6.1 \\
<0.05\end{array}$ & $\begin{array}{l}74 \cdot 0 \\
\pm 5 \cdot 6 \\
\text { NS }\end{array}$ & $\begin{array}{l}71 \cdot 2 \\
\pm 1 \cdot 8 \\
\text { NS }\end{array}$ & $\begin{array}{l}73 \cdot 2 \\
\pm 7 \cdot 7 \\
\text { NS }\end{array}$ \\
\hline $\begin{array}{l}\text { Nitroblue } \\
\text { tetrazolium } \\
\quad \mathbf{P}\end{array}$ & $\begin{array}{r}6.6 \\
\pm 1.0\end{array}$ & $\begin{array}{l}51 \cdot 2 \\
\pm 4.5 \\
<0.001\end{array}$ & $\begin{array}{l}47.6 \\
\pm 8.0 \\
<0.001\end{array}$ & $\begin{array}{l}28.6 \\
\pm 3.2 \\
<0.001\end{array}$ & $\begin{array}{l}44.4 \\
\pm 4.0 \\
<0.001\end{array}$ \\
\hline
\end{tabular}


Table 8 Effect of nylon wool contact on enzyme scores (mean $\pm S E M$ for five experiments)

\begin{tabular}{|c|c|c|c|c|}
\hline & \multicolumn{2}{|c|}{30 minutes' contact } & \multicolumn{2}{|c|}{60 minutes' contact } \\
\hline & Control & Test & Control & Test \\
\hline $\begin{array}{l}\text { Chloroacetate esterase } \\
\text { P }\end{array}$ & $\begin{array}{r}95 \cdot 0 \\
\pm 2 \cdot 3\end{array}$ & $\begin{array}{l}114.2 \\
\pm 0.6 \\
<0.001\end{array}$ & $\begin{array}{r}93.4 \\
\pm 4.8\end{array}$ & $\begin{array}{l}113.8 \\
\pm 2.7 \\
<0.01\end{array}$ \\
\hline $\begin{array}{l}\text { Acid phosphatase } \\
\text { P }\end{array}$ & $\begin{array}{r}5.4 \\
\pm 0.9\end{array}$ & $\begin{array}{l}14.4 \\
\pm 0.9 \\
<0.001\end{array}$ & $\begin{array}{r}5.4 \\
\pm 0 \cdot 2\end{array}$ & $\begin{array}{l}15 \cdot 6 \\
\pm 1 \cdot 2 \\
<0.001\end{array}$ \\
\hline $\begin{array}{l}\text { Neutrophil alkaline } \\
\text { phosphatase } \\
\quad \text { P }\end{array}$ & $\begin{array}{r}16.2 \\
\pm 2.5\end{array}$ & $\begin{array}{l}19 \cdot 4 \\
\pm 2 \cdot 3 \\
\mathrm{NS}\end{array}$ & $\begin{array}{r}18 \cdot 0 \\
\pm 2 \cdot 3\end{array}$ & $\begin{array}{l}19 \cdot 0 \\
\pm 2 \cdot 8 \\
\mathrm{NS}\end{array}$ \\
\hline $\begin{array}{l}\text { Nitroblue tetrazolium } \\
\text { P }\end{array}$ & $\begin{array}{r}19.0 \\
\pm 1.6\end{array}$ & $\begin{array}{l}22 \cdot 4 \\
\pm 2 \cdot 4 \\
\text { NS }\end{array}$ & $\begin{array}{r}17 \cdot 2 \\
\pm 2 \cdot 6\end{array}$ & $\begin{array}{l}23 \cdot 4 \\
\pm 3 \cdot 6 \\
\text { NS }\end{array}$ \\
\hline
\end{tabular}

trast, latex particle ingestion did not increase enzyme scores. The NAP scores did not increase in any experiment, but the NBT scores increased significantly after phagocytosis of either organisms or latex.

EFFECT OF NYLON WOOL CONTACT

Aliquots $(2.5 \mathrm{ml})$ of LRP were incubated at $37^{\circ} \mathrm{C}$ with $150 \mathrm{mg}$ nylon wool fibre (Fenwal Laboratories) in plastic syringes for 30 or 120 minutes. Control syringes, containing LRP but no nylon wool, were incubated under identical conditions. The LRP was then expelled from the syringes, and the cells were washed and tested cytochemically as before. The results (Table 8) show a significant increase in activity of the primary lysosomal enzymes but no significant increase for NAP and NBT.

\section{Discussion}

The cytochemical technique developed in this study used unfixed cells, suspended in a reaction mixture of physiological osmolality, to avoid gross damage to the neutrophil cytoplasmic membrane, which can affect lysosomes within the cell (Dumonde et al., 1965). Adjustment of osmolality was necessary since isolated primary lysosomes are more susceptible to rupture in hypotonic media than the secondary granules (Bainton, 1973). The duration of incubation was adjusted to give little or no reaction product in intact cells so that any membrane damage would give a visible cytochemical reaction for chloroacetate esterase or acid phosphatase.

In contrast, a conventional NAP reaction was performed on neutrophils in which the lysosomal membranes had already been rendered fully permeable by drying and fixation. Membrane active agents would not therefore be expected to increase NAP positivity since the cytochemical technique alread $\stackrel{0}{\vec{D}}$ showed 'maximal' activity. Similarly, the NBT score, which reflects cytoplasmic rather than lysosoma秀 membrane activity, should not be increased by agente롱 which act on lysosomal membranes.

Reduction of pH to below 5.0 is known to labilis lysosomal membranes (De Duve et al., 1955; Chayen et al., 1971), and this was demonstrated for the new technique by incubation at low $\mathrm{pH}$ before the chloros acetate esterase reaction, which is performed $\vec{a} \vec{D}$

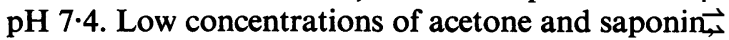
which also increase membrane permeability, causeg్f an increase in demonstrable activity of both chloro. acetate esterase and acid phosphatase withou increasing either the NAP or NBT reactions.

Although these experiments show an effect o lysosomal membranes it is clearly difficult to exclude a simultaneous effect by an external agent on the cytoplasmic membrane; both membranes presum ably became labilised in these experiments. McCaH et al. (1969) concluded that toxic granulation is an alteration in primary lysosomal membranes and they showed by electron microscopy that the toxic granule is not an autophagic body; but again it was not possible in our experiments to exclude the formation of secondary autophagic lysosomes with conses quential increased membrane permeability.

The in vitro effects of bacteria and bacteria products are relevant to the diagnostic value of these lysosomal enzyme tests in infected patients. Endo $\overrightarrow{5}$ toxin, which stimulates the cytoplasmic membrane to phagocytose and reduce NBT (Park and Good 1970), did not increase demonstrable lysosomal. enzyme activity whereas Streptolysin $O$, which reacts with membrane lipids to form submicroscopic holes (Peter and Smith, 1977) and causes early lysosoma membrane damage (Hirsch et al., 1963), resulted in substantial increase. Phagocytosis of latex particles increased the NBT score only, whereas phagocytosis of live organisms increased both the NBT score and primary lysosomal enzyme activity. As expected, the NAP activity in fully labilised lysosomes did not increase.

The cell suspension method does, therefore, appearic to reflect increased lysosomal membrane permet ability caused by certain physical agents and bacteriø్g or bacterial products. This has been demonstrated for two enzymes but other primary lysosomal ene zymes could probably be used since membran $\$$ permeability to substrate, rather than the activity of a particular enzyme, is the main determinant of the cytochemical reaction. It might also be of value to develop a similar membrane-sensitive technique fof the NAP reaction in secondary lysosomes but the precise intracellular localisation of this enzyme \& still under debate. 
Preliminary studies (unpublished) in patients with localised and systemic bacterial infection have shown elevated scores for chloroacetate esterase and acid phosphatase. These enzymes should now be studied in parallel with the NAP and NBT reactions to determine whether simultaneous testing of different aspects of neutrophil metabolism in patients with bacterial infection can improve diagnostic precision. The new technique also proved sensitive to contact with nylon wool in vitro, and since lysosomal enzyme release has already been used as a marker of cell damage in the preparation of neutrophil concentrates (Klock and Bainton, 1976) the method may also be of value in assessing cell damage during filtration leucopheresis.

We are indebted to the Leukaemia Research Fund and to the West Midlands Regional Health Authority for financial support.

\section{References}

Ackerman, G. A. (1962). Substituted naphthol AS phosphate derivatives for the localisation of leukocyte alkaline phosphatase activity. Laboratory Investigation, 11, 563-567.

Allison, A. C., and Mallucci, L. (1965). Histochemical studies of lysosomes and lysosomal enzymes in virusinfected cell cultures. Journal of Experimental Medicine, 121, 463-476.

Bainton, D. F. (1973). Sequential degranulation of the two types of polymorphonuclear leukocyte granules during phagocytosis of microorganisms. Journal of Cell Biology, 58, 249-264.

Bainton, D. F. (1975). Neutrophil granules. British Journal of Haematology, 29, 17-22.

Bainton, D. F., and Farquhar, M. G. (1966). Origin of granules in polymorphonuclear leukocytes. Two types derived from opposite faces of the Golgi complex in developing granulocytes. Journal of Cell Biology, 28, 277-301.

Bainton, D. F., Ullyot, J. L., and Farquhar, M. G. (1971). The development of neutrophilic polymorphonuclear leukocytes in human bone marrow: origin and content of azurophil and specific granules. Journal of Experimental Medicine, 134, 907-934.

Burstone, M. S. (1962). Enzyme Histochemistry, p. 259. Academic Press, New York and London.

Chayen, J., Bitensky, L., Butcher, R. G., and Cashman, B. (1971). Evidence for altered lysosomal membranes in synovial lining from human rheumatoid joints. Beiträge zur Pathologie, 142, 137-149.

Cline, M. J. (1975). The White Cell, p. 17. Harvard University Press, Cambridge, Massachusetts.

Cohn, Z. A., and Hirsch, J. G. (1960). The isolation and properties of the specific cytoplasmic granules of rabbit polymorphonuclear leucocytes. Journal of Experimental Medicine, 112, 983-1004.

De Duve, C. (1959). Lysosomes, a new group of sub- cellular particles. In Subcellular Particles, edited by T. Hayashi, pp. 128-159. Ronald Press, New York.

De Duve, C. (1969). The lysosome in retrospect. In Lysosomes in Biology and Pathology, edited by J. T. Dingle and H. B. Fell, vol. 1, pp. 3-40. North Holland, Amsterdam.

De Duve, C., Pressman, B. C., Gianetto, R., Wattiaux, R., and Applemans, F. (1955). Tissue fractionation studies, 6. Intracellular distribution patterns of enzymes in rat-liver tissue. Biochemical Journal, 60, 604-617.

Dumonde, D. C., Bitensky, L., Cunningham, G. J., and Chayen, J. (1965). The effects of antibodies on cells. I. Biochemical and histochemical effects of antibodies and complement on ascites tumour cells. Immunology, 8, 25-36.

Gordin, R. (1952). Toxic granulation in leukocytes: development and relation to cloudy swelling. Acta Medica Scandinavica, Supplement 270.

Gordon, P. A., Stuart, J., Lee, T. R., Breeze, G. R., and Pugh, R. N. H. (1975). The cytocentrifuge NBT test. Journal of Clinical Pathology, 28, 674-679.

Hayhoe, F. G. J., and Quaglino, D. (1958). Cytochemical demonstration and measurement of leucocyte alkaline phosphatase activity in normal and pathological states by a modified azo-dye coupling technique. British Journal of Haematology, 4, 375-389.

Hirsch, J. G., Bernheimer, A. W., and Weissmann, G. (1963). Motion picture study of the toxic action of streptolysins on leucocytes. Journal of Experimental Medicine, 118, 223-228.

Klock, J. C., and Bainton, D. F. (1976). Degranulation and abnormal bactericidal function of granulocytes produced by reversible adhesion to nylon wool. Blood, 48, 149-161.

McCall, C. E., DeChatelet, L. R., Cooper, M. R., and Shannon, C. (1973). Human toxic neutrophils. III. Metabolic characteristics. Journal of Infectious Diseases, 127, 26-33.

McCall, C. E., Katayama, I., Cotran, R. S., and Finland, M. (1969). Lysosomal and ultrastructural changes in human 'toxic' neutrophils during bacterial infection. Journal of Experimental Medicine, 129, 267-293.

Park, B. H., and Good, R. A. (1970). NBT test stimulated (Letter). Lancet, 2, 616.

Peter, G., and Smith, A. L. (1977). Group A streptococcal infections of the skin and pharynx. Part I. New England Journal of Medicine, 297, 311-317.

Segal, A. W. (1974). Nitroblue-tetrazolium tests. Lancet, 2, 1248-1252.

Steigbigel, R. T., Johnson, P. K., and Remington, J. S. (1974). The nitroblue tetrazolium reduction test versus conventional hematology in the diagnosis of bacterial infection. New England Journal of Medicine, 290, 235-238.

Wintrobe, M. M. (1974). Clinical Hematology, 7th edition, p. 1278. Lea and Febiger, Philadelphia.

Requests for reprints to: Dr John Stuart, Department of Haematology, The Queen Elizabeth Hospital, Queen Elizabeth Medical Centre, Edgbaston, Birmingham B15 2TH. 